\title{
Tradisi Ngokoi Okan Perentehu Dayak Lawangan: Pendekatan Fungsional Struktural Talcott Parson
}

\author{
Ervantia Restulita L. Sigai
}

\begin{abstract}
Abstrak
Praktik tradisi ngokoi okan perentehu terdapat nilai-nilai, norma dan kepercayaan yang berfungsi sebagai pedoman yang memberi orientasi kepada kehidupan komunitas Dayak Lawangan. Teori fungsionalisme struktural memandang masyarakat sebagai suatu sistem, secara fungsional. Menurut Talcott Parson fungsi adalah kumpulan kegiatan yang ditujukan menunjangn keseimbangan dan pemenuhan kebutuhan sistem. Aktivitas tradisi ngokoi okan perentehu merupakan perwujudaan sebuah sistem keseimbangan yang fungsinya saling beradaptasi, pencapaian tujuan yang sama kepada Jo'us Tuha Allah Tala, berintegrasi dalam pranata kehidupan Dayak Lawangan dan pemeliharaan pola dalam tradisi yang berjalan dan dilestarikan antar generasi yang melahirkan fungsi religius, fungsi norma sosial, dan fungsi estetika.
\end{abstract}

Kata kunci: ngokoi okan perentehu, Dayak Lawangan

\section{The Tradition of Ngokoi Okan Perentehu Dayak Lawangan: Functional Structural Approach Talcott Parson}

\begin{abstract}
Implementation of tradition ngokoi okan perentehu there are values, norms and beliefs that serve as a guide that gives orientation to life Dayak Lawangan community. The theory of Functionalism structural views society as a system, functionally. According to Talcott Parson function is a collection of activities aimed at supporting the balance and fulfillment of system requirements. Traditional activity of Ngokoi okan perentehu is the embodiment of a balance system whose function of adaptation, the achievement of the same goal to Jo'us Tuha Allah Tala, integrates in the life of Dayak Lawangan and maintenance of the pattern in tradition that runs and is preserved between generations which gave birth to the religious function social norms, and aesthetic functions.
\end{abstract}

Keywords: ngokoi okan perentehu, Dayak Lawangan

\section{Pendahuluan}

Globalisasi adalah penyebaran praktik, relasi, kesadaran, dan organisasi di seluruh penjuru dunia. Hampir setiap bangsa dan jutaan orang di seluruh dunia mengalami transformasi, sering dramatis, yang disebabkan globalisasi (Ritzer, 2012: 976). Hal ini memberikan dampak dalam berbagai aspek kehidupan sosial dan budaya masyarakat. Terjadinya perubahan secara langsung maupun tidak langsung 
akan menggeser tata nilai yang lama dengan tata nilai yang baru di masyarakat.

Hal ini dipertegas oleh Kleden (1987: 239) bahwa kalau sistem budaya ini tidak cukup kuat lagi untuk menjadi landasan sistem sosial, maka perubahan akan terjadi. Pada lapisan material kebudayaan akan muncul semacam entropi kebudayaan, di mana sistem nilai kebudayaan bersangkutan tidak mati, tetapi kehilangan dayanya untuk memotivasi dan mengontrol sistem sosial yang ada. Perubahanperubahan itu terjadi dan akan mempengaruhi sistem budaya masyarakat termasuk kearifan lokal yang ada di masyarakat. Walaupun demikian, bukan berarti globalisasi begitu saja dapat menyebabkan perubahan budaya suatu masyarakat tanpa reaksi masyarakat yang bersangkutan, karena sebagaimana dikemukakan Naisbitt dan Aburdene (dalam Ardika, 2007: viii) bahwa kecendrungan lain yang muncul di era globalisasi sekarang ini adalah semacam penolakan (counter trend) terhadap homogenitas budaya, sehingga timbul hasrat untuk menegaskan keunikan kultural dan bahasa. Menurut Suraya (2011: 6) kearifan lokal sebagai bagian dari tradisi lisan dapat diperhitungkan sebagai realitas nilai budaya alternatif dalam kehidupan global berada dalam dua sistem budaya yang harus dipelihara dan dikembangkan, yakni sistem budaya nasional dan sistem budaya lokal.

Nilai budaya nasional berlaku secara umum untuk seluruh bangsa, sekaligus berada di luar ikatan budaya lokal mana pun. Nilai-nilai kearifan lokal tertentu akan bercitra Indonesia karena akan dipadu dengan nilai-nilai lain yang sesungguhnya diwariskan dari nilai-nilai budaya lokal. Tradisi lisan memegang peranan penting dan strategis dalam kehidupan masyarakat Indonesia, karena tradisi lisan sebagai salah satu bentuk budaya lokal yang memiliki hubungan batin dengan para pewarisnya dan diyakini dapat dimanfaatkan untuk meningkatkan kualitas kehidupan masyarakat pendukungnya. Tradisi lisan memiliki peranan penting dan fungsi untuk menguatkan ketahanan budaya bangsa. Hanya saja, seiring perkembangan zaman, kian banyak tradisi lisan yang mulai hilang dan untuk melestarikannya harus memerlukan waktu dan keahlian tersendiri untuk mengiventarisir dan mengkaji berbagai tradisi yang ada di masyarakat.

Komunitas Dayak Lawangan memiliki tradisi lisan yang dikenal ngokoi okan perentuhu. Tradisi dilakukan dalam upaya untuk memohon keselamatan dalam kehidupan serta ungkapan syukur atas keberhasilan panen yang ditujukan kepada mahluk halus dan roh-roh leluhur. Tradisi ngokoi 
okan perentuhu merupakan salah satu bentuk kearifan lokal yang hingga kini masih dikenal oleh komunitas etnis dayak Lawangan di Desa Bantai Karau, kecamatan Dusun Tengah, kabupaten Barito Timur, provinsi Kalimantan Tengah.

Tradisi lisan sebagai titik tolak penelitian ini merupakan suatu bentuk upaya agar tradisi lisan tersebut dapat dimanfaatkan, dikembangkan, direvitalisasi, dan dilestarikan (Sigai, 2016: 8). Tradisi ngokoi okan perentuhu sebagai suatu bentuk kebudayaan yang perlu dijaga dari ancaman kepunahannya demi keberlanjutan tradisi komunitas etnis Dayak Lawangan. Berdasarkan uraian di atas akan dibahas salah satu aspek dari tradisi ngokoi okan perentehu, bagaimana fungsi tradisi ngokoi okan perentuhu komunitas etnis Dayak Lawangan di Desa Bantai Karau, Kecamatan Dusun Tengah, Kabupaten Barito Timur, Provinsi Kalimantan Tengah.

\section{Pembahasan}

\subsection{Kajian Pustaka}

Kajian secara khusus mengenai tradisi ngokoi okan perentuhu komunitas etnis Dayak Lawangan di Desa Bantai Karau, Kecamatan Dusun Tengah, Kabupaten Barito Timur, Provinsi Kalimantan Tengah di Desa Timur, Kalimantan Tengah belum pernah diteliti sebelumnya. Namun beberapa penelitian kearifan lokal dan tradisi yang relevan dijadikan rujukan guna mendukung dan memberi inspirasi dalam penelitian ini.

Karya Suraya (2011) yang berjudul Kearifan lokal Tradisi Kasalasa dalam Perladangan Berpindah pada Komunitas Petani Etnis Muna Kabupaten Muna Provinsi Sulawesi Tenggara. Penelitian ini membahas kearifan lokal tradisi Kasalasa dalam perladangan berpindah pada komunitas petani etnis Muna. Pada dasarnya tradisi Kasalasa ini telah berlangsung sejak lama di kalangan petani yang dilakukan sebelum memulai kegiatan perladangan pada musim barat (bhara). Sebagai akibat modernisasi dan masuknya paham pembaharuan pada ajaran Islam, nilai-nilai yang terkandung dalam Kasalasa tidak dipahami lagi seutuhnya. Penelitian ini bertujuan untuk mengungkap bentuk, fungsi dan makna yang terkandung dalam kearifan lokal tradisi Kasalasa. Tradisi Kasalasa, memberikan gambaran bahwa begitu banyak nilai-nilai, norma-norma serta adat-istiadat yang terkandung di dalam tradisi tersebut yang merupakan kearifan lokal yang dapat diterapkan dalam kehidupan sehari-hari, meskipun kita tengah berada dalam erah modernisasi dan globalisasi.

Perbedaan yang mendasar dari kajian kasalasa yang diutarakan di atas lebih menfokuskan kepada tradisi 
perladangan. Sedangkan pada kajian ini lebih memfokuskan pada aspek kearifan lokal yang bersifat religio magis dalam kaitannya dengan keseimbangan kehidupan manusia dalam hubugannya dengan lingkungan alam, manusia, leluhur dan ungkapan syukur kepada Jo'us Tuha Allah Tala (Tuhan) dengan segala bentuk manifestasinya terutama fokus pada aspek fungsi dari sebuah tradisi.

Penelitian lain Sigai (2016) Eksistensi Balian Bawo Dayak Lawangan di Dusun Tengah, Barito Timur, Kalimantan Tengah mengkaji eksistensi balian bawo dalam era globalisasi telah membawa implikasi ke dalam kehidupan masyarakat Dayak Lawangan di Dusun Tengah, Barito Timur, Kalimantan Tengah. Salah satunya terlihat dari keberadaan balian bawo belakangan ini yang semakin langka tereduksi oleh modernisasi. Pada saat ini para penutur balian bawo tersebut semakin berkurang jumlahnya, mulai kehilangan generasi penerus. Realitas keberadaan balian bawo mengarah kepada kelangkaan padahal eksistensi balian bawo dalam berbagai segi bagi komunitas Dayak Lawangan masih berfungsi untuk kehidupan mereka. Penelitian Sigai menjadi acuan untuk melihat pranata kehidupan sosial budaya komintas Dayak Lawangan di Dusun Tengah. Perbedaan dengan penelitian yang akan dilakukan adalah pada penelitian Sigai mengkaji eksistensi balian bawo dan kearifan lokal dalam cakupan yang lebih luas, sedangan pada penelitian ini lebih fokus kepada tradisi ngokoi okan perentuhu yang menfokuskan kajian pada aspek fungsi.

Hasil penelitian yang telah dikemukakan di atas dijadikan sebagai sumber data sekunder yang akan digunakan sebagai bahan pembanding dan pelengkap, sedangkan sumber data primer yang akan digali di lapangan. Sumber data primer yang paling utama adalah informasi hasil eksplorasi dari para narasumber.

\subsection{Teori Fungsionalisme} StrukturalPada hakikatnya teori digunakan untuk menjelaskan mengapa sesuatu terjadi yang berlaku dalam kenyataan, teori melaksanakan fungsi ganda yaitu pertama, menjelaskan fakta yang sudah diketahui, dan kedua, membuka celah pandangan baru untuk menemukan fakta baru. Bila kejadian yang sama ditafsirkan dalam konteks teoretis berbeda, akan muncul jenisjenis fakta yang berlainan pula (Kaplan, 2002: 15). Jadi, teori sebagai panduan menganalisis dan mengembangkan pikiran dalam upaya menjawab masalah yang dikaji. Pada penelitian ini menggunakan pendekatan atau teori fungsional struktural

Teori fungsionalisme struktural memandang masyarakat sebagai suatu 
sistem, secara fungsional berada dalam kondisi eqiuliubirum dikenal dengan integrationapproach, order approach, equilibrium, atau lebih populer dengan sebutan stuructural-functional approach (Nasikun, 1995: 4-9).

Menurut Talcott Parson (dalam Ritzer, 2012: 407-410), fungsi adalah kumpulan kegiatan yang ditujukan kearah pemenuhan kebutuhan sistem, selanjutnya Parson mengatakan ada empat fungsi penting mutlak dibutuhkan bagi semua sistem sosial, yang meliputi, adaptasi (A), pencapaian tujuan atau goal attainment (G), integrasi (I), dan latensi (L). Empat fungsi tersebut wajib dimiliki oleh semua sistem agar tetap bertahan (survive). Berikut penjelasannya mengenai skema AGIL menurut Parson berikut ini.

1. Adaptasi (adaptation) merupakan fungsi yang amat penting, di sini sistem harus dapat beradaptasi dengan cara menanggulangi situasi eksternal yang gawat, dan sistem harus bis a menyesuaikan diri dengan lingkungan juga dapat menyesuaikan lingkungan untuk kebutuhannya.

2. Pencapaian tujuan (goal attainment) yaitu sebuah sistem yang harus mendefinisikan dan mencapai tujuan utamanya.
3. Integrasi (integrations), sebuah sistem harus mengatur antarhubungan bagian-bagian yang menjadi komponen. Sistem juga harus mengelola antahubungan ketiga fungsi penting lainya $(A, G, L)$

4. $\quad \mathrm{L}$ a t e n s i a $\mathrm{tau}$ pemeliharaan pola (latency) sebuah sistem harus $\mathrm{m}$ e $\mathrm{mper} l$ e $\mathrm{ng} \mathrm{k}$ a $\mathrm{i}$, me melih ara, d a n memperbaiki, baik motivasi individual maupun pola-pola kultural yang menciptakan dan menopang motivasi.

Pendekatan fungsional struktural sebagaimana dikembangkan oleh Talcott Persons dan didasarkan pada pendekatan integrasi dapat dilihat $d$ ari anggapan dasar yang dikembangkan yaitu; (1) masyarakat harus dilihat sebagai suatu sistem dari pada bagian-bagian yang saling berhubungan satu sama lain, (2) hubungan saling pengaruh mempengaruhi di antara bagian-bagian tersebut adalah bersifat ganda dan timbal balik, (3) sekalipun integrasi sosial tidak pernah dapat dicapai dengan sempurna, namun secara fundamental bergerak ke arah equilibrium yang bersifat dinamis, (4) sekalipun disfungsi ketegangan dan penyimpanganpenyimpangan senantiasa terjadi juga, 
akan tetapi di dalam jangka panjang keadaan tersebut pada akhirnya akan teratasi dengan sendirinya melalui penyesuaian-penyesuian dan proses instutisionalisasi, (5) perubahanperubahan di dalam sistem sosial pada umumnya akan terjadi secara gradual, melalui penyesuaian, dan tidak secara revolusioner, (6) perubahan-perubahan terjadi melalui tiga macam kemungkinan yaitu penyesuaianpenyesuaian yang dilakukan oleh sistem sosial tersebut terhadap perubahan yang datang dari luar, perubahan-perubahan melalui proses diferensiasi struktur fungsional, serta penemuan baru oleh masyarakat, (7) faktor terpenting yang memiliki daya untuk mengintegrasi suatu sistem sosial adalah konsesus di antara anggota-anggotanya mengenai nilai kemasyarakatan tertentu (Nasikun, 1995: 11-12).

Teori fungsionalisme-struktural dalam penelitian ini digunakan untuk memahami nilai-nilai budaya maupun norma yang berlaku/berfungsi berkenanaan dengan fungsi tradisi ngokoi okan perentuhudalam komunitas Dayak Lawangan. Peneliti melihat bahwa dalam konteks tradisi ngokoi okan perentuhu merupakan fakta sosial. Bagaimana nilai, norma dan budaya komunitas etnis Dayak Lawangan berfungsi.

\subsection{Metode Penelitian}

Penelitian ini merupakan penelitian kebudayan yang menggunakan metode kualitatif dan teknik analisis deskriptif-kualitatif. Menurut Faisal (2001: 15) metode kualitatif berkaitan erat dengan sifat unik dari realitas sosial dan dunia tingkah laku manusia itu sendiri. Sedangkan menurut Suparlan (1994: 25) yang menjadi sasaran kajian atau penelitian kualitatif adalah kehidupan sosial atau masyarakat sebagai kesatuan yang menyeluruh (holistic). Penekanannya bukan pada pengukuran, akan tetapi lebih pada penjelasan yang bersifat holistik sehingga pendekatan yang digunakan adalah pendekatan kajian budaya, yakni pendekatan etnografi, tekstual, dan resepsi (Barker, 2006:29).

Jenis data dalam penelitian ini adalah data kualitatif dan didukung data kuantitatif. Jenis data kualitatif berupa narasi, kata-kata, ungkapan maupun uraian yang berkaitan dengan tradisi ngokoi okan perentuhu. Adapun jenis data kuantitatif dalam penelitian ini merupakan data pelengkap baik berupa a ngka-angka maupun statistik berhubungan dengan gambaran umum wilayah, seperti komposisi jumlah penduduk, agama dan kepercayaan. Sumber data, yaitu sumber data primer dan sumber data sekunder. Data primer adalah data yang diperoleh di lapangan, 
hasil wawancara dengan informan, sedangkan sumber data sekunder diperoleh melalui penelusuran berupa pustaka,penelitian terdahulu yang relevan dan data pendukung lainnya yang memperkaya penelitian ini.

Penentuan informan penelitian adalah informan yang dipilih berdasarkan teknik purposive sampling, yaitu dipilih informan yang mempunyai pengetahuan dan pengalaman mengenai tradisi ngokoi okan perentuhu. Teknik penentuan informan purposive sampling adalah menentukan subjek atau objek sesuai tujuan dengan menggunakan pertimbangan pribadi yang sesuai dengan topik penelitian, peneliti memilih subjek atau objek sebagai unit analisis (Satori, 2010: 47).

Instrumen penelitian yang akan digunakan dalam penelitian ini adalah pedoman wawancara dan pedoman pengamatan. Daftar pertanyaan ini mengacuaspek fungsi tradisi ngokoi okan perentuhu komunitas etnis Dayak Lawangan. Penelitian ini menggunakan paradigma naturalistik yang salah satu karakteristiknya adalah human instrument (Danim, 2002: 135). Karakteristik manusia sebagai instrumen penelitian lebih mampu menyesuaikan diri dengan situasi tertentu, dapat membangun pengetahuan yang terkatakan maupun yang tak terkatakan (Lincoln dan Guba, 1985: 39).
Pengumpulan data yang dilakukan dalam penelitian ini adalah menggunakan teknik penelitian lapangan (field research), yakni peneliti melakukan pengumpulan data secara langsung di lokasi penelitian dengan menggunakan teknik observasi, wawancara, dan studi dokumen. Observasi merupakan kegiatan pengumpulan data. Observasi dilakukan secara sistematis maupun observasi partisipan.Observasi partisipan pada suatu pihak merupakan "orang dalam" yang merasakan dan mengalami situasi secara pribadi. Di lain pihak ia juga "orang luar" yang dapat mengamati situasi dengan sikap yang lebih objektif. Manfaat observasi partisipan akan memperat hubungan peneliti dengan informan, sehingga data yang diperoleh semakin leluasa. Lebih dari itu, keterbukaan informan juga akan semakin lebar. Peneliti juga lebih memahami dari berbagai aspek atas budaya yang diteliti (Endraswara, 2006: 142).

Penelitian ini menggunakan wawancara mendalam (Indepth Interview) dilakukan dengan cara tatap muka dan tanya jawab secara langsung dengan informan untuk mendapatkan informasi secara bebas dan mendalam mengenai fungsi tradisi ngokoi okan perentuhu dan dilakukan dengan teknik pertanyaan terbuka (open-ended interview). Teknik pertanyaan terbuka 
membuka kebebasan kepada informan untuk menjawab secara luas dengan bahasa, gayanya sendiri, lebih fleksibel terhadap situasi dan kondisi informan. Jawaban-jawaban tersebut dicatat, direkam oleh peneliti. Seluruh informasi diperoleh dari informan akan dijadikan bahan dasar, kemudian diklasifikasikan sesuai dengan kategori atau pengelompokan dalam analisis penelitian ini.

Pada penelitian kualitatif ini sebagai pelengkap digunakan studi dokumen. Dokumen merupakan sumber informasi non human resources. Peneliti mencari berbagai data terutama bukubuku yang cakupan bahasannya menyangkut tradisi ngokoi okan perentuhu. Sedangkan teknik Analisis Data dilakukan secara deskriptif kualitatif dan interpretatif. Data yang sejak observasi ditelaah dari berbagai sumber, yaitu wawancara dan pengamatan yang terdiri dari catatan lapangan dan komentar peneliti, gambar, foto, artikel dan sebagainya. Teknik analisis data terdiri atas tiga proses yang saling terkait (Huberman dan Miles, 2009: 592), yaitu: (1) reduksi data (data reduction), (2) penyajian data (data display), dan (3) pengambilan simpulan atau verifikasi.

2.4. Potret Desa Bantai Karau, Kecamatan Dusun Tengah, Kabupaten Barito Timur

Penelitian ini difokuskan di Desa
Bantai Karau, Kabupaten Barito Timur, Provinsi Kalimantan Tengah (lihat gambar 1.1). Lokasi ini dipilih dengan pertimbangan sebagai berikut: (1) Pada masyarakat tersebut masih melakukan tradisi ngokoi okan perentuhu. (2) lokasi tersebut penduduknya adalah relatif homogen, yakni etnis Dayak Lawangan. (3) komunitas etnis Dayak Lawangan yang berdomisili di daerah tersebut mayoritas beragama Hindu (Hindu Kaharingan).

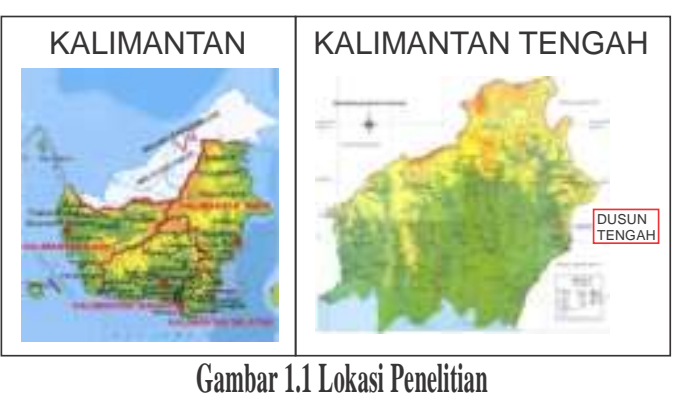

Sumber: Diadaptasi dari Pemerintah Daerah Kalimantan Tengah (2013)

Desa Batai Karau terletak di Kecamatan Dusun Tengah, Kabupaten Barito Timur, Provinsi Kalimantan Tengah. Luas wilayah Kecamatan Dusun Tengah lebih kurang $371 \mathrm{~km}^{2}$ atau 9,68\% dari luas wilayah Kabupaten Barito Timur. Kecamatan Dusun Tengah berbatasan dengan lima kecamatan dan satu provinsi yaitu sebelah utara berbatasan dengan Kecamatan Raren Batuah, sebelah barat berbatas dengan Kecamatan Pematang Karau, sebelah Selatan berbatas dengan Kecamatan Paku, Kecamatan Awang, Kecamatan Patangkep Tutui, dan sebelah Timur dengan wilayah Provinsi Kalimantan 
Selatan. Kecamatan Dusun Tengah terdiri atas satu kelurahan dan tujuh desa definitif, yaitu Kelurahan Ampah Kota, Desa Saing, Desa Rodok, Desa Ampah Dua, Desa Putai, Desa Netampin, Desa Sumber Garunggung, dan Desa Muara Awang. Desa Muara Awang dan Desa Netampin merupakan dua desa terluas.

Kecamatan Dusun Tengah merupakan kecamatan dengan jumlah penduduk, rumah tangga, dan kepadatan tertinggi di Kabupaten Barito Timur. Jumlah penduduk Dusun Tengah pada tahun 2013 berjumlah 24.573 jiwa, 6.318 rumah tangga dengan kepadatan penduduk $66,23 \mathrm{jiwa} / \mathrm{km}^{2}$ dan mengalami peningkatan signifikan di setiap tahunnya (lihat gambar 1.2).

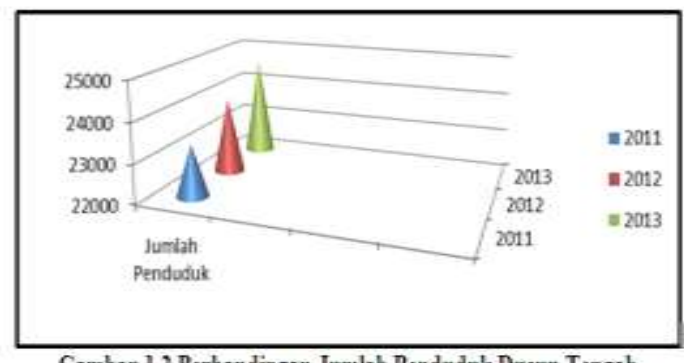

Gambar 1.2 Perbandingan Jumlah Penduduk Dusun Tengah Sumber: Diolah Dari Dusan Tengah Dalam Angka 2014

Penduduk kecamatan Dusun Tengah beragama yaitu (1) agama Islam, (2) agama Kristen Protestan, (3) agama Katolik, dan (4) agama Hindu.Mayoritas pendidikan kecamatan Dusun Tengah beragama Islam. Penduduk Dusun Tengah menurut agama pada umumnya sama karateristiknya dengan penduduk beragama di wilayah lain di Indonesia. Komposisi dan persentasi penduduk berdasarkan agama di Dusun Tengah digambarkan dalam data tabel 1. 1 sebagai berikut.

Tabel 1. 1

Komposisi \& Persentase Penduduk Berdasarkan Agama di Dusun Tengah

\begin{tabular}{|c|c|c|c|}
\hline$S_{0}$ & Pemeluk Agama & Jumlah Jiwa & Persentasi $(9 i)$ \\
\hline 1 & Islam & 2164 & 29,28 \\
\hline 2 & Knisten Protestan & 2930 & 40,31 \\
\hline 3 & Katelik & 1300 & 1759 \\
\hline 4 & Hindis & 948 & $12 \$ 2$ \\
\hline 5 & Budha & 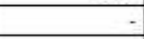 & 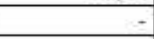 \\
\hline 6 & Khonghusu & 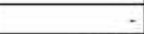 & - \\
\hline & Jumlah & 7392 & 100 \\
\hline
\end{tabular}

Sumber: Kementrian Agama Kabupaten Barito Timur Tahun 2012

\subsection{Tradisi Ngokoi Okan Perentuhu}

Tradisi ngokoi okan perentehu sistem ritus dan upacara dalam religi berwujud aktivitas dan tindakan manusia dalam melaksanakan baktinya terhadap Tuhan, Dewa-dewa, roh nenek moyang, atau makhluk halus lain. Ritus atau upacara religi biasanya terdiri atas suatu kombinasi berdoa, bersujud, bersaji, berkorban, makan bersama, menari dan menyanyi. Menurut Piliang (2005), konsep tradisi dapat didefenisikan sebagai setiap bentuk karya, gaya, konvensi atau kepercayaan yang dipresentasikan sebagai kelanjutan dari masa lalu ke masa kini. Tradisi dengan demikian adalah sesuatu yang tidak pernah berubah, dan dijalankan sebagai sebuah pengulanganpengulangan (repetition). Tradisi adala "repetisi “ dan "reproduksi". Tradisi dilanjutkan dari satu generasi ke generasi berikutnya sebagai sebuah pengetahuan (knowledge), kebernaran 
(truth), yang tidak perlu dipertanyakan atau diinterpretasikan (reinterpretation) inilah pengertian konvensional tradisi.

Tradisi ngokoi okan perentuhu merupakan kebiasan yang dilakukan oleh komunitas etnis Dayak Lawangan yang berlangsung sejak lama dan diwariskan secara turun temurun. Tradisi ngokoi okan perentuhu sebagai pranata sosial budaya komunitas etnis Dayak Lawangan dan merupakan wahana rekonsiliasi dengan Tuhan, roh alam, dan roh leluhur. Tradisi ngokoi okan perentuhu permohonan keselamatan, kebahagian dan ungakapan syukur kepada alam semesta, leluhur dan Jo'us Tuha Allah Tala.

Tradisi ngokoi okan perentehu dilaksankan oleh komunitas Dayak Lawangan. Menurut Durasid (1990: 47) menyatakan kelompok Barito itu dibagi atas tiga subkelompok, yaitu Barito Barat, yang terdiri atas bahasa Kahayan dan Dohoi, Barito Timur yang terdiri atas bahasa Maanyan dan subkelompok Lawangan-Dusun Deyah (yang terpisah menjadi bahasa Lawangan dan Duson Deyah), dan Barito - Mahakam, di sini diwakili bahasa Tunjung. Penutur bahasa Lawangan bermukim di kabupaten administratif Barito Timur dan sekitarnya. Penelitian ini memfokuskan sub suku Dayak yang diteliti adalah komunitas etnis Dayak Lawangan yang berdomisili di Desa Bantai Karau, Kecamatan Dusun
Tengah, Kabupaten Barito Timur, Kalimantan Tengah yang memiliki keyakinan Kaharingan atau dikenal luas di Kalimantan Tengah sebagai Hindu Kaharingan.

Tradisi ngokoi okan perentuhu adalah salah satu kegiatan ritual yang dilakukan pada setiap awal panen beras pertama. Aktivitas ini sudah sejak lama dilakukan oleh petani yang bermukim di Desa Bantai Karau karena diyakini memiliki nilai-nilai religius dan merupakan wujud ungkapan syukur kepada semesta alam dengan harapan panen berikutnya akan memperoleh hasil yang berlimpah dan tidak mengalami gagal panen. Menurut pandangan Suraya (2011: 106) berikut ini:

Jika interaksi antara manusia dengan alam sudah terwujudkan, akan tetapi interaksi manusia dengan manusia (sebagai mahluk sosial) dan interaksi manusia dengan leluhur dan maha pencipta serta interaksi dengan roh-roh halus baik itu roh yang baik maupun yang jahat belum terpenuhi, maka pola ideal interaksi belum tercapai. Karena itu setiap perilaku manusia baik disengaja maupun tidak disengaja harus memiliki fungsi tertentu. Dalam melakukan tindakan, manusia mempunyai tujuan-tujuan tertentu yang dapat berguna bagi kelangsungan hidupnya baik untuk kepentingan individu, kelompok (sosial) bahkan kepentingan untuk dengan leluhur serta sang pencipta. 
Tradisi ngokoi okan perentuhu menunjukkan kearifan yang sangat bermanfaat bagi kelangsungan lingkungan. Pengharagaan atas hasil alam dan kerja keras manusia. Bentuk kearifan lokal tradisi ngokoi okan perentuhu dalam hubungannya dengan kegiatan perladangan. Semua aspek dalam tradisi ngokoi okan perentuhu merupakan komponen dari emosi keagamam, sistem keyakinan, sistem ritual dan keyakinan umat. Komponen tradisi ngokoi okan perentuhu tersebut melahirkan fungsi tradisi ngokoi okan perentuhu bagi komunitas Dayak Lawangan, yaitu fungsi religius, fungsi norma sosial, fungsi estetika, makna simbolis dan religius, makna pelesarian budaya, dan makna kehidupan sosial.

\section{Fungsi Tradisi Ngokoi Okan Perentuhu}

Kearifan sosiofak menggambarkan wujud tingkah laku manusia dalam kebudayaan, misalnya menari, berbicara, tingkah laku dalam melakukan suatu pekerjaan, dan lainlain. Kebudayaan dalam wujud ini masih bersifat konkret, dapat difoto, dan dapat difilm. Semua aktivitas dan perilaku pola tingkah manusia merupakan bagian dari sistem sosial. Fungsi tradisi ngokoi okan perentuhu, yaitu: (1) fungsi religius, (2) fungsi norma sosial, dan (3) fungsi estetika.

\section{Fungsi Religius}

Sistem upacara merupakan wujud kelakuan dan religi dan seluruh sistem tradisi ngokoi okan perentuhu adalah sesuatu hal yang wajib di lakukan oleh warga Desa Bantai Karau Dayak Lawangan setiap tahun. Dibandingkan tempat lain di kecamatan Dusun Tengah tradisi ngokoi okan perentuhu lebih sering dilaksanakan. Pelaksanaan tradisi ngokoi okan perentuhu tergantung masih-masing keluarga. Tradisi ngokoi okan perentuhu dianggap merupakan bagian dari kehidupan yang berkaitan dengan kesimbangan mikrokosmos dan makrokosmos. Dalam melaksanakan tradisi ngokoi okan perentuhu, melibatkan beberapa pihak yakni keluarga besar, serta tokoh-tokoh adat yang ada dalam wilayah setempat. Para keluarga berkumpul dan b e r m u s y a w a r a h u $\mathrm{n} \mathrm{uk}$ menyelenggaraan ngokoi okan perentuhu, terutama yang putra tertua dalam keluarga. Seperti ungkapan Sutria (wawancara, 12 Oktober 2016) berikut ini.
"Pelaksaaan ngokoi okan perentuhu ini yang melaksakaan adalah anak laki-laki tertua dari keluarga, apabila anak laki-laki sudah meninggal maka akan diteruskan dari garis keturuannya dan harus laki-laki. Seperti saya ini merupakan keturunan dari garis keturunan laki-laki.Bila dari garis keturunan perempuan 
tidak bisa, tidak tau pasti mengapa tidak bisa tapi aturannya dari dulu begitu. Pihak perempuan membantu sarana dan prasarana untuk acara seperti sesajan".

Ungkapan di atas menunjukkan bahwa putra berjenis kelamin laki-laki lebih banyak dituntut tanggungjawab untuk keluarga, menjaga pusaka keluarga dan meneruskan tradisi. Hal ini menunjukan kedudukan laki-laki lebih utama dalam pelaksanaan tradisi ngoko $i$ okan perentuhu. Namun kedudukan perempuan tidak serta merta diabaikan dalam ungkapan Sutria tersebut tersirat bahwa terjadi pembagian kerja antara perempuan dan laki-laki. Para laki-laki fokus pada pelaksaaan ritual sedangkan perempuan mempersiapkan sarana dan prasarana upacara. Semua bagian dari keluarga ayah, ibu dan anak, masingmasing mengambil peran untuk menyediakan segala sesuatu yang dibutuhkan dalam penyelenggaraan, dan pada umumnya dilakukan secara kolektif dalam keluarga besar.

Tradisi ngokoi okan perentuhu d a 1 a m pelaks a n a n n y a mempersembahkan beberapa bahanbahan, baik itu yang diperoleh dari alam/ kebun, maupun yang dibuat sendiri oleh manusia. Setiap keluarga yang menyelenggarakan ngokoi okan perentuhu, menyediakan jenis-jenis persembahan sesuai dengan kemampuannya. Hal ini menunjukkan pelaksanaan tradisi disesuaikan deng kondisi finasial masing-masing keluarga. Persembahan utama dalam tradisi ngokoi okan perentuhu sederhana seperti ungkapan Sahrani Awal (wawancara, 13 Oktober 2016) dan Eben Tube (wawancara, 12 November

2016) berikut ini.

“Persembahan untuk pelaksanaan acara ngokoi okan perentehu sederhana, yang utama disiapkan ayam, beras, ketan, sipa rokok dan tampung tawar. Persembahan yang lain terserah kita sesuai dengan kemampuan. Pada pelaksanaan acara itu dimohonkan, keselamatan, berkah, dan rejeki. Apabila yang diharapkan dikabulkan maka tahun dapat akan menyelenggarakan upacara yang lebih besar. Misalnya kalau sekarang ayamnya satu, tahun depan memperoleh rejeki lebih maka tahun depan kaul lebih besar lagi. Sajennya akan ditambahkan dan dilipan gandakan, misalnya sajen ayamnya sekarang satu, besok menjadi dua atau lebih banyak lagi”.

Ungkapan di atas menunjukkan jenis persembahan utama terdiri dari ayam, beras, ketan, sipa rokok dan tampung tawar. Pernyataan tersebut juga mengunkapakan harapan dari masing-masing keluarga yang melaksanakan tradisi ngokoi okan perentuhu. Jika panen tahunan berhasil, permohonan kaul terpenuhi dan 
pendapatan meningkat, maka jenis-jenis persembahan beragam dan banyak. Bagi Dayak Lawangan tardisi ngokoi okan perentehu difungsikan secara praktis untuk perbaikan-perbaikan dalam kehidupan seperti mengharapkan hasil panen yang lebih baik, terhindar dari bencana alam atau wabah penyakit, mepemperoleh rejeki dan pengungkapan rasa syukur terhadap yang maha kuasa dan alam semesta (mikrokosmos dan makrokosmos).

\section{Fungsi Norma Sosial}

Warga Desa Bantai Karau yang akan menyelenggarakan tradisi ngokoi okan perentuhu bermusyawarah untuk menentukan tempat di mana kegiatan akan dilaksanakan. Biasanya hasil dari musyawarah tersebut sebagai pedoman. Pada musyawarah tersebut, para tetua adat atau kepala keluarga yang dituakan melakukan pembagian tugas untuk menangani setiap bagian yang diperlukan dalam tradisi ngokoi okan perentuhu. Misalnya, pembagian tugas untuk mencari bahan yang dibutuhkan sebagai kelengkapan sarana ngokoi okan perentuhu, sampai dengan yang bertugas untuk membuat anyaman sebagai wadah ngokoi okan perentuhu, serta yang bertugas mempersiapkan tetua adat sebagai pimpinan dalam melakukan tradisi tersebut.

Setelah semua peralatan yang diperlukan dalam acara ngokoi okan perentuhu tersebut tersedia, keluarga besar yang mempunyai hajatan berkumpul di dalam rumah untuk pelaksanaan ngokoi okan perentuhu. Semua keluarga besar berkumpul, istri, akan muda bahkan anak-anak pun hadir untuk mengikuti pelaksanaan ngokoi okan perentuhu.

\section{Fungsi Estetika}

$\mathrm{K}$ e a r i f n s o s i of a $\mathrm{k}$ menggambarkan wujud tingkah laku manusia dalam kebudayaan, misalnya menari, berbicara, tingkah laku dalam melakukan suatu pekerjaan, dan lainlain. Kebudayaan dalam wujud ini masih bersifat konkret, dapat difoto, dan dapat difilm. Pelaksanaan ritual tradisi ngokoi okan perentuhu mengekpresikan totalitas kosmosnya bentuk persembahan. Ungkapan estetika dalam bentuk persembahan secara langsung ekspresi religi dan bersifat sakral. Seperti ungkapan Makur (wawancara, 12 November 2016) "bentuk persembahan dibuat indah sedemikian rupa untuk menunjukkan rasa bakti". Ungkapan Makur menunjukkan persembahan sesajen mengekspresikan rasa baktinya dan getaran jiwa keilahian. Sejalan yang disampaikan oleh Hauser (dalam Relin D.E, 2011: 296) bahwa karya seni sejak manusia mulai melakukan ekspresi diri, merupakan perwujudan terjadinya komunikasi, khususnya terhadap 
hakikat supranatural.

\section{Simpulan}

Pendharmawacana adalah seseoPraktik tradisi ngokoi okan perentehu terdapat nilai-nilai, norma dan kepercayaan yang berfungsi sebagai pedoman yang memberi orientasi kepada kehidupan komunitas Dayak Lawangan, yaitu: pertama, tradisi ngokoi okan perentuhu adalah salah satu kegiatan ritual yang dilakukan pada setiap awal panen beras pertama. Aktivitas ini sudah sejak lama dilakukan oleh petani yang bermukim di Desa Bantai Karau merupakan wujud ungkapan syukur dan pengharapan kepada semesta alam dan leluhur. Penghormatan kepada Jo'us Tuha Allah Tala, leluhur dan alam semesta bermakna mengingatkan manusia mengenai keberadaannya dan harus senantiasa berprilaku sesuai tuntuna, memperlakukan alam semesta dengan bijaksana, memelihara hubungan yang harmonis dengan sesama dan leluhur. Kedua, tradisi ngokoi okan perentuhu berjalan secara turun-temurun sehingga merupakan sebuah konstruksi budaya yang berkaitan dengan keyakinan yang mereka anut dan berfungsi hingga saat ini.

\section{DAFTAR PUSTAKA}

Ardika, I Wayan.2007. Pusaka Budaya dan Pariwisata. Denpasar: Pustaka Larasan.

Barker, Chris. 2006. Cultural Studies: Teori dan Praktik.(Tim KUNCI Cultural Studies Centre, Pentj). Yogyakarta: Bentang Budaya.

Danim, Sudarwan. 2002. Menjadi Penelitian Kualitatif: Rancangan Metodologi, Presentasi, dan Publikasi Hasil Penelitian untuk Mahasiswa dan Peneliti Pemula Bidang IlmuIlmu Sosial, Pendidikan, dan Humaniora. Bandung: CV. Pusaka Setia.

Durasid, Durdje. 1990. "Rekonstruksi Protobahasa Barito" (disertasi). Jakarta: Fakultas Pascasarjana Universitas Indonesia.

Dusun Tengah Dalam Angka 2014. 2014. Badan Pusat Stastistik, K abupaten Barito Timur, Provinsi Kalimantan Tengah.

Endaswara, Suwardi. 2006. Metodologi Penelitian Kebudayaan. Yogyakarta: Pustaka Widyatama.

Faisal, Sarapiah. 2001. Varian-Varian Kontemporer Penelitian Sosial. Dalam: Burhan Bugin.,(ed). Metode Penelitian Kualitatif. Jakarta: PT. Raja Grasindo Persada.

Hubermen, A. Michael., Mattew B. Miles. 2009. "Manajemen Data dan Metode Analisis". Dalam: Denzin, Norman K., \& Lincoln, Yvonna S., (ed). Handbook of Qualitative Research (Dariyatno, dkk, Pentj). Yogyakarta: Pustaka Pelajar. Hal: 591-612.

Kaplan, David \& Robert A. Manners. 2002. Teori Kebudayaan. (Landung Simatupang, Pentj). Yogyakarta: Pustaka Pelajar. 
Kleiden, Ignas. 1987. Sikap Ilmiah dan Kritik Kebudayaan. Jakarta: LP3S.

Koentjaraningrat.1985.Ritus Peralihan Di Indonesia. Jakarta: PN. Balai Pustaka.

Budhisantoso., J.

Danandjaya, Pasudi Suparlan, E.K.M. Masinambow., A. Sofion. 2003. Kamus Istilah Antropologi. Jakarta: Pusat Bahasa Departemen Pendidikan Nasional.

Lincoln, Yvonna S., Egon G. Guba. 1985. Naturalistic Inquiry. California: SAGE Publication. Inc.

Nasikun.1995. Sistem Sosial di Indonesia. Jakarta: PT. Grafindo Persada.

Piliang. 2005. "Menciptakan Keunggulan Lokal untuk Merebut Peluang Global: Sebuah Pendekatan Kultural". Naskah Seminar Membedah Keunggulan Lokal dalam Konteks Global. Denpasar: Institut Seni Indonesia (ISI).

Relin D.E. 2011. "Pemertahanan Tradisi Ruwatan dalam Era Modernisasi dalam Masyarakat Jawa di Desa Kum endung, Muncar, Banyuwangi, Jawa Timur" (disertasi). Denpasar: Program Pascasarjana, Universitas Udayana.

Ritzer. 2012. Teori Sosiologi: Dari Sosiologi Klasik Sampai Perkembangan Terakhir Postmoderen. (Saut Pasaribu, dkk, Pentj). Yogyakarta: Pustaka Pelajar.

Satori, Djam'an., Komariah, Aan. 2010. Metodologi Penelitian Kualitatif. Bandung: Alfabeta.

Sigai, Ervantia Restulita. 2016. "Eksistensi Balian Bawo Dayak Lawangan di Dusun Tengah, Barito Timur, Kalimantan
Tengah”. Disertasi. Denpasar: P rogram Pasacasarjana, Universitas Udayana.

Suparlan, Parsudi. 1994. Metode Penelitian Kualitatif. Jakarta: Program Kajian Wilayah Amerika-Universitas Indonesia.

Suraya, Rahmat Sewa. 2011. "Kearifan

Lokal Tradisi Kasalasa dalam

Perladangan Berpindah pada

Komunitas Petani Etnis Muna

Kabupaten Muna Provinsi Sulewaesi

Tenggara". Tesis. Denpasar: Program

Pasacasarjana, Uiversitas Udayana. 
Dharma Duta

Jurnal Penerangan Agama Hindu Vol. 16 No. 1, 2018 